\title{
Integrated Twin Tower (ITT) Based Learning to Think (LTT) Model to Enhance Scientific Creativity and Spiritual of students in the Early Childhood Islamic Education Department
}

\author{
R Pangastuti ${ }^{1}$, N Fadhillah ${ }^{2}$ \\ ${ }^{1}$ Department of Early Childhood Islamic Education, UIN Sunan Ampel Surabaya, Surabaya 60237, Indonesia \\ 2Department of Science and Technology, UIN Sunan Ampel Surabaya, Surabaya 60237, Indonesia
}

\begin{tabular}{l} 
Article Info \\
Article history: \\
Received April 2, 2020 \\
Revised April 19, 2020 \\
Accepted April 20, 2020 \\
\hline
\end{tabular}

Keywords:

Integrated Twin Tower

Learning to Think

Early Childhood Islamic Education

Scientific Creativity

Spiritual

\begin{abstract}
The Indonesian National Qualification Framework in higher education requires universities to develop a curriculum so that students have superior competence with a variety of skills that are appropriate to the needs of the $21^{\text {st }}$ century in the field of enhancing creative thinking skills. Expectations about the importance of scientific and spiritual creativity of Students of Early Childhood Islamic Education department based on the above literature review contradict the results of preliminary studies by researchers. The results of preliminary studies that there are complex problems that must be resolved immediately, and learning innovation and development of lecture devices that are specifically designed to develop scientific and spiritual creativity of students in the Early Childhood Islamic Education Department in UINSA is very needed. An alternative solution to the above problems that are offered by researchers is to develop an Integrated Twin Tower-based Learn to Think (LTT) learning model to enhance scientific and spiritual creativity of students in the Early Childhood Islamic Education Department. This model was developed by correcting the weaknesses of the LTT model and adding Integrated Twin Tower in each syntax based on the literature review that has been done before. Integrated Twin Tower is an innovative idea that has been developed at The Faculty of Tarbiyah and Teacher Training of UINSA with the foundation of thinking that the learning process cannot be separated between the core scientific fields of study and the Islamic values
\end{abstract}

\section{INTRODUCTION}

Curriculum demands and the development of the globalization era require educational institutions to innovate that benefit the $21^{\text {st }}$ century skills-based education world (Turiman, Omar, Daud, \& Osman, 2012; Griffin, \& Care, 2015). The Indonesian National Qualification Framework in higher education requires universities to develop curriculum so that students have superior competence with a variety of skills that are in line with the demands of the $21^{\text {st }}$ century including creative thinking skills (Perpres, 2012). The $21^{\text {st }}$ century learning requires human resources with the competence and achievements that are directed to the learning skills and innovations, including critical thinking skills, problem-solving skills, decision making, creative thinking, responsible, and able to learn independently (Partnership for 21st Century Skills, 2014; Griffin \& Care, 2015). Creativity in learning science is known as scientific creativity (Mukhopadhyay \& Sen, 2013). Scientific creativity is needed by students to solve various real-life problems (OECD, 2014); adapt to new demands flexibly (Greiff et al., 2014; Stenberg, 2009); scientific discovery and technological innovation (ADB, 2014; Dhir, 2014). Based on these competencies, the Islamic University of Sunan 
Ampel Surabaya (UINSA) has a significant role in pursuing the quality of the learning process and outcomes, including the learning process and outcomes of students in the Early Childhood Islamic Education department. UINSA conducts effective and efficient learning to improve students' scientific creativity by not leaving the spiritual aspect as a basic strength and characteristic of UINSA as one of the Islamic Teacher Training Institutions in Indonesia.

Expectations regarding the importance of scientific and spiritual creativity of students in the Early Childhood Islamic Education Department based on the above literature study contradict the results of preliminary studies by researchers. The results of the preliminary study in the even semester of 2016/2017 school year and the odd semester of 2017/2018 school year that have been conducted at UINSA, especially for students and lecturers of the Early Childhood Islamic Education Department Education Program, in general, are as follows. 1) The scientific creativity of students in the Early Childhood Islamic Education Department has generally classified as low criteria; 2) The spiritual aspects of students in the Early Childhood Islamic Education Department in general still need to be improved; 3) Lecturers in the classroom learning have not improved scientific and spiritual creativity of students in the Early Childhood Islamic Education Department; 4) The majority of learning processes use conventional models (lectures, discussions, and presentations) and rarely do experiments in the laboratory so that they have not been able to optimally increase the scientific creativity of students in the Early Childhood Islamic Education Department; 5) There is no lecture device which was developed specifically to improve scientific and spiritual creativity of students in the Early Childhood Islamic Education Department in UINSA. The results of the initial study can be used as evidence of complex problems that must be resolved immediately, and learning innovation and development of lecture devices that are specifically designed to develop scientific and spiritual creativity of students in the Early Childhood Islamic Education Department in UINSA are much needed.

The results of previous research related to innovative learning that already exists to enhance scientific creativity include Learn to Think (LTT). LTT was developed specifically to improve students' thinking skills ( $\mathrm{Hu}, \mathrm{Wu}, \mathrm{Jia}, \mathrm{Yi}$, Duan, \& Meyer, 2013). Thinking activities in LTT train students to think critically and creatively through concrete, abstract, and creative thinking activities. LTT uses students thinking methods to develop student creativity directly in the learning process, stimulates students' interest and motivation to learn from the beginning to the end of learning, develops metacognition effectively, and creates an open, democratic, and positive atmosphere. Students are given more time to discuss problems with the team, think independently, dare to convey ideas and assess the views of others $(\mathrm{Hu}, \mathrm{Wu}, \mathrm{Jia}, \mathrm{Yi}, \mathrm{Duan}, \&$ Meyer, 2013). The results of the literature study show the advantages of LTT as follows; 1) Developed to improve students' thinking skills in physics, chemistry, biology, geography, mathematics, and other disciplines. 2) Enhance the ability to find science problems creatively, design products creatively, increase the use of a product technically, solve science problems creatively, and imagine science creatively $(\mathrm{Hu}$, Wu, Jia, Yi, Duan, \& Meyer, 2013). However, LTT also has the following weaknesses; 1) Lack of training the ability to determine the use of objects for scientific purposes and to design experiments creatively. 2) Developed for secondary schools so it needs to be reviewed if it is applied for higher education $(\mathrm{Hu}, \mathrm{Wu}, \mathrm{Jia}, \mathrm{Yi}$, Duan, \& Meyer, 2013). Besides, no research implements LTT to improve the spiritual aspects of students in the Early Childhood Islamic Education Department. Based on the literature review above, it shows that the LTT still has weaknesses and must be corrected to improve the scientific and spiritual creativity of students in the Early Childhood Islamic Education Department.

An alternative solution to the above problems that are offered by researchers is to develop an LTT learning model based on ITT to enhance the scientific and spiritual creativity of students in the Early Childhood Islamic Education Department. This model was 
developed by correcting the weaknesses of the LTT model and adding an Integrated Twin Tower in each syntax based on a literature review that has been done before. Integrated Twin Tower is an innovative idea that has been developed at The Faculty of Tarbiyah and Teacher Training of UINSA with the foundation of thinking that the learning process cannot be separated between the core scientific fields of study and the Islamic values. This innovative idea will be used as a basis for learning in the classroom to increase the scientific and spiritual creativity of students in the Early Childhood Islamic Education Department. There is a great hope that the innovative the LTT learning model based on ITT that is developed by researchers can be an alternative solution and can be a strength of UINSA as one of the Educational Institutions of the Educational Personnel in preparing students in the Early Childhood Islamic Education Department to become a golden generation in 2045.

\section{DISCUSSION}

\section{Scientific Creativity}

Creativity is one of the human basic needs; it is the need for self-realization or selfactualization and is the highest need for humans. Everyone is born in the world with creative potential. Creativity can be identified and fostered through proper education. Creativity is also the power or ability of humans to create things. This ability can be related to the arts and science. In the field of art, intuition and inspiration play a big role and is according to higher spontaneity. In the field of science, the ability to observe and compare, analyze and conclude is more decisive. Both require disconnection, ability, paperwork and perseverance, both depart from intellectualism and emotion, and are the ways of recognizing the same reality of nature and life.

There are many definitions of creativity, but there is no definition that can be universally accepted. To further explain the notion of creativity, several formulations will be put forward, which are the experts' conclusions about creativity. Creativity is a unique mental process, a process that is merely done to produce something called "difference thinking" (dive thinking). Creativity is the ability of a person to produce any composition, product or idea that is new and previously unknown to the creator. The many definitions of creativity are one of the critical problems in researching, identifying and developing creativity. Creativity is the process of sensitivity to problems, identifying problems, formulating hypotheses, testing hypotheses, the possibility of modifying and re-testing hypotheses, and communicating the results (Fauziah et al., 2018; Torrance, 2013; Siswanto, 2018; Suyidno et al., 2018).

Creativity in learning science is known as scientific creativity (Mukhopadhyay \& Sen, 2013; Suyidno et al., 2017; Suyidno et al., 2018; Suyidno et al., 2019; Suyidno et al., 2020). Scientific creativity is needed by students to solve various real-life problems (OECD, 2014); adapt to new demands flexibly (Greiff et al., 2014; Stenberg, 2009); scientific discovery and technological innovation (ADB, 2014; Dhir, 2014). Hu \& Adey (2010) recommends scientific creativity in class that emphasizes: (a) determining the use of an object for scientific purposes (unusual uses); (b) the level of sensitivity to scientific problems (problem finding); (c) increasing the technical use of a product (product improvement); (d) scientific imagination (e) creatively science problem solving; (f) designing experiments creatively; and (g) design a product creatively. Based on the explanation above, the seven indicators of scientific creativity above are the main components of the science-learning model to train students' scientific creativity.

\section{Students' Spiritual Aspects}

Spirituality and religion are different but always hand in hand. Spirituality looks deeper into the mind toward awareness of someone's universal values. While religion looks out of 
someone's self by using formal rites (religious ordinances) and scriptures. Religion looks more at an external orientation while spirituality includes how a person looks into his mind. So, spirituality can be reached by all people who are religious or not. Spirituality is a process of transformation through various integrated aspects of life including physical, emotional, work, intellectual and rational. Spirituality is closely related to creativity, love, forgiveness, compassion, trust, respect, wisdom, faith, and a sense of unity.

As humans, we are formed from the body, mind, emotions, and spirit. Spirituality gives an expression that there is something inside us; associated with feelings, with the power that comes from within us, by knowing our deepest self. Spirituality is a term that many people want to be included in our lives. Spirituality can reflect values such as contributing to humanity and the universe. The role of spirituality is very important for our lives both in family life, religion and even in our work life

Spirituality has two components, namely vertical and horizontal. The vertical component of spirituality is the desire to go beyond the ego or self-esteem. This vertical component can relate to God, the soul, the universe, the highest power or something else. The horizontal component is more a manifestation of something that cannot be seen. Meanwhile, the horizontal component in spirituality is the desire to serve others and the earth. This horizontal component is shown by how a person tries to make a difference through his actions. This horizontal component is more a manifestation of something that can be seen. Spirituality helps individuals find meaning and purpose in their lives and more shows their value. These personal values reflect a desire to make a difference and help to make the world more meaningful. Therefore, having spirituality in daily life is very important to make us become a whole and meaningful individual.

Students' spiritual aspects are reflected in their daily activities that can be accounted for based on Islamic values (Perpres, 2012, Kemdikbud, 2016). The indicators of spiritual aspects in this study include prayer, worship, greetings, gratitude, and tawakal. More specifically, it can be explained as follows. 1) Pray before and after doing something. 2) Worship, performing worship on time; respect for other people who are performing worship according to their religion; 3) Greetings, greetings at the beginning and the end of the presentation according to the adopted religion; 4) Gratitude, grateful for the blessings and gifts from the Almighty God; grateful for the ability of humans to control themselves; give thanks when successfully doing something; 5) Tawakal, surrender to God after endeavoring or making an effort.

\section{Integrated Scientific and Spiritual Creativity of students in the Early Childhood Islamic Education Department}

The Faculty of Tarbiyah and Teacher Training of UINSA maximally combines and synergizes Islamic studies (Naqliyah Science) and Education studies (Aqliyah Science) both at the faculty and study program levels as a form of Integrated Twin Tower. Lecturers are encouraged to design their learning from the formulation of objectives, materials, learning experiences, learning strategies and methods as much as possible linking to the two wings of Islam and science (science, social sciences, humanities and education). The learning process cannot be separated between the core scientific fields of study and the Islamic values. This innovative idea will be used as a basis for learning in the classroom to increase the scientific and spiritual creativity of students in the Early Childhood Islamic Education Department.

Integrated Twin Tower (ITT)-based Learning to Think (LTT) Learning Model to Increase Scientific and Spiritual Creativity of students in the Early Childhood Islamic Education Department

The problem-based learning model with a scientific approach based on twin tower integration called the LTT learning model based on ITT is formulated based on the results of theoretical and preliminary \& development studies. The LTT learning model based on ITT 
was developed referring to the characteristics of the learning model according to Arends (2012) as it states that there are four special features of the learning model that can be used to achieve learning objectives effectively, namely the logic design of the Theoretical rationales, the learning objectives to be achieved, the behavior of lecturers in teaching the needed learning, and a supportive learning environment to achieve the learning objectives. In summary, the characteristics of the LTT learning model based on ITT can be explained as follows.

\section{- Theoretical rationales}

The development of learning processes in the LTT learning model based on ITT refers to John Dewey's problem-solving flow (Arends, 2012) and the scientific creativity hypothesis (Hu \& Adey, 2010), and supported by the latest learning theories (constructivism theory), metacognitive skills, reciprocal relationships, complex cognitive processes, advanced organizers, and scaffolding). These four theories become the foundation in developing the LTT learning model based on ITT that can increase the scientific and spiritual creativity of students in the Early Childhood Islamic Education Department. These theories become the basis in preparing learning steps for the LTT learning model based on ITT, which consists of five phases, namely: 1) Learning Orientation, 2) Scientific Activities, 3) Reflection of Scientific Activity Processes, 4) Expansion of Activities, and 5) Evaluation.

Phase 1: Learning Orientation, introducing activities, setting learning situations through cognitive conflict is very effective for stimulating students' thinking and constructing their enthusiasm for learning in accommodating conceptual frameworks for new things. Supported by the following learning theories. The cognitive learning view emphasizes the mental processes that underlie new information processing, such as paying attention to explanations, interpreting graphs, or linking new concepts with their prior knowledge (Moreno, 2010). Advanced organizers help lecturers direct students to the studied material and help to remember related information that can help bring new information (Slavin, 2011). Strengthened by relevant research results that scientific investigations can motivate students to control their learning processes (Liu \& Lin, 2013; Zakar \& Baykara, 2014).

Phase 2: Scientific Activities, students are facilitated to observe, think, discuss, and experiment. They are encouraged to explore their learning methods and strategies to actively master the material. Supported by the following learning theories. Complex cognitive processes are needed to use or transform previous knowledge and skills into creative products (Eggen \& Kauchak, 2013). A creative product includes the results of divergent thinking (creativity). Creativity is the ability to generate new ideas, combine ideas in new ways, or unique problem solving (Moreno, 2010). Strengthened by relevant research results that are needed to create a free, open, democratic, and positive learning atmosphere as the key to the development of scientific creativity (Hu, Wu, Jia, Yi, Duan, \& Meyer, 2013).

Phase 3: Reflection on Scientific Activity Processes, students are guided to reflect on the learning process to master what has been learned in Scientific Activity. Supported by the following learning theories. Based on cognitive distribution theory, conveying ideas to others can improve their understanding because they are encouraged to clarify and organize ideas, describe known information, find flaws in reasoning, and provide alternative perspectives that are as valid as their thoughts (Moreno, 2010). Vygotsky introduced the Zone of Proximal Development (ZPD), which is the distance between the actual level of development (ability to solve problems independently) and the level of potential development (problem-solving abilities under the guidance of more capable adults or peers). Students work in ZPD when they are unable to solve their problems, but can solve problems after getting the right help from an adult or a friend (Slavin, 2011). Strengthened 
by relevant research results that creativity can be developed through the delivery of ideas and evaluation of other people's ideas (Gregory, Hardiman, Yarmalinskaya, Rinne, \& Limb, 2013),

Phase 4: Expansion of Activities, involving the expansion of activities, students are required to apply and transfer what is learned in activities of daily life. Supported by the following learning theories. Bandura theorizes that learning is the result of observing others or observing the consequences of other people's behavior. Learning through observation includes: (a) attention, paying attention to relevant information from the observed model, (b) retention, remembering the observed behavior to imitate it in the future, (c) production, converting mental representations that are created during coding for the motor activity, (d) motivation, motivated to learn from the model and reproduce what is learned. Bandura introduced the reciprocal causation model to show the interrelationship between the environment, behavior, and personal beliefs. Strengthened with relevant research results that the task of creativity can be done by applying, generating, discovering, imagining and planning creative ideas (Rotteram, 2014).

Phase 5: Evaluation, students conduct evaluation processes and learning outcomes to increase scientific creativity and spiritual aspects of students in the Early Childhood Islamic Education Department. Supported by the learning theories of; 1) Self-evaluation, judging if the outcome of someone's actions or strategies is acceptable or unacceptable (Moreno, 2010); 2) Last effects (recency effects); the tendency for items that appear at the end is easier to be remembered than other items (Slavin, 2011). Strengthened by relevant research results that the involvement of students' roles in planning, implementing, and evaluating the learning process contributes significantly to the achievement of their responsibilities (Yesil, 2013).

Table 1. Syntax of LTT Learning Model based on ITT, Scientific Creativity Indicators, and Spiritual Aspect Indicators

\begin{tabular}{|c|c|c|}
\hline $\begin{array}{l}\text { Syntax of LTT } \\
\text { Learning Model } \\
\text { based on ITT }\end{array}$ & Scientific Creativity Indicators & $\begin{array}{l}\text { Spiritual Aspect } \\
\text { Indicators }\end{array}$ \\
\hline Phase 1: & Unusual uses; Problem finding; Product improvement; & Pray; Worship; \\
\hline Learning & Scientific imagination; Creatively science problem & Greetings, \\
\hline Orientation & $\begin{array}{l}\text { solving; Creatively experiment designing; Creatively } \\
\text { product design }\end{array}$ & $\begin{array}{l}\text { Gratitude; and } \\
\text { Tawakal }\end{array}$ \\
\hline Phase 2: & Unusual uses; Problem finding; Product improvement; & Pray; Gratitude; \\
\hline Scientific Activity & $\begin{array}{l}\text { Scientific imagination; Creatively science problem } \\
\text { solving; Creatively experiment designing; Creatively } \\
\text { product design }\end{array}$ & \\
\hline Phase 3: & Unusual uses; Problem finding; Product improvement; & Pray; Gratitude; \\
\hline Reflections on the & Scientific imagination; Creatively science problem & and Tawakal \\
\hline Process of Scientific & solving; Creatively experiment designing; Creatively & \\
\hline Activity & product design & \\
\hline Phase 4: & Unusual uses; Problem finding; Product improvement; & Pray; Gratitude; \\
\hline $\begin{array}{l}\text { Expansion of } \\
\text { Activity }\end{array}$ & $\begin{array}{l}\text { Scientific imagination; Creatively science problem } \\
\text { solving; Creatively experiment designing; Creatively } \\
\text { product design }\end{array}$ & and Tawakal \\
\hline Phase 5: & Unusual uses; Problem finding; Product improvement; & Pray; Worship; \\
\hline \multirow[t]{3}{*}{ Evaluation } & Scientific imagination; Creatively science problem & Greetings, \\
\hline & solving; Creatively experiment designing; Creatively & Gratitude; and \\
\hline & product design & Tawakal \\
\hline
\end{tabular}




\section{- Learning objectives to be achieved}

The purpose of developing the LTT learning model based on ITT to be able to increase scientific and spiritual creativity of students in the Early Childhood Islamic Education Department and other goals that are generating activities, student responses, and increasing student motivation in learning.

\section{- Lecturer behavior in teaching}

To optimize the impact of the LTT learning model based on ITT application, which is to improve the scientific and spiritual creativity of students in the Early Childhood Islamic Education Department, both instructional impact and accompaniment impact, it will be described regarding the implementation of the model in terms of lecturer ways in managing learning, which includes: (a) planning tasks; (b) interactive tasks; (c) learning environment and task management; and (d) evaluation. The things done in the planning tasks are (a) formulating goals; (b) choosing content, (c) carrying out task analysis; and (d) planning time and space.

\section{CONCLUSION}

Integrated Twin Tower is an innovative idea that has been developed at The Faculty of Tarbiyah and Teacher Training of UINSA with the foundation of thinking that the learning process cannot be separated from the core scientific fields of study and the Islamic values. Development of the learning process in LTT based on ITT refers to John Dewey's problemsolving plot and $\mathrm{Hu} \&$ Adey's scientific creativity hypothesis and is supported by the latest learning theories (constructivist theory, metacognitive skills, reciprocal relationships, complex cognitive processes, advanced organizer, and scaffolding). These four theories become the foundation in developing the LTT learning model that can increase the scientific and spiritual creativity of students in the Early Childhood Islamic Education Department. These theories become the basis in preparing learning steps for the LTT based on ITT, which consists of five phases, namely: 1) Learning Orientation, 2) Scientific Activities, 3) Reflections on Scientific Activity Processes, 4) Expansion of Activities, and 5) Evaluation. The limitation of this study is that it is still in a hypothetical model product. Therefore, further research still needs to be done to test the validity, practicality and effectiveness of the LTT learning model based on ITT.

\section{ACKNOWLEDGMENTS}

The researchers would like to thank UIN Sunan Ampel Surabaya for providing research grant funds (Decree of the Rector of UIN Sunan Ampel Surabaya Number 704 of 2019).

\section{REFERENCES}

ADB. (2014). Creative productivity index: Analysing creativity and innovation in Asia. A report by the economist intelligence unit for the Asian Development Bank August 2014. The Economist Intelligence Unit Ltd. and Asian Development Bank.

Arends, R.I. (2012). Learning to teach. New York: Mc. Graw-Hill.

Dhir, T. (2014). Problem solving ability and science process skills as the influential factors of scientific creativity. International Journal of Research Pedagogy and Technology in Education Movement Sciences, 2(4), 11-17.

Eggen, P.D., \& Kauchak, D.P. (2013). Educational psychology. New Jersey: Pearson.

Fauziah, C., Nuvitalia, D., \& Saptaningrum, E. (2018). Model project based learning (PjBL) berbasis lesson study terhadap kemampuan berpikir kreatif siswa SMA. Jurnal Penelitian Pembelajaran Fisika, 9(2), 125-132. 
Gregory, E., Hardiman, M., Yarmolinskaya, J., Rinne, L., \& Limb, C. (2013). Building creative thinking in the classroom: From research to practice. International Journal of Educational Research, 62, 43-50.

Greiff, S., Wustenberg, S., Csapo, B., Demetriou, A., Hautamaki, A., Graesser, A. C., \& Martin, R. (2014). Domain-general problem solving skills and education in the 21st century. Educational Research Review, 13, 74-83.

Griffin, P., \& Care, E. (2015). Assesment and teaching of 21st century skills: Methods and approach. New York: Springer.

Hu, W., \& Adey, P. (2010). A scientific creativity test for secondary school students. International Journal of Science Education, 24(4), 389-403.

Hu, W., Wu, B., Jia, X., Yi, X., Duan, C. \& Meyer, W. (2013). Increasing student's scientific creativity: The "learn to think" intervention program. The Journal of Creative Behavior, $47(1), 3-21$.

Kemdikbud. (2016). Salinan lampiran peraturan menteri pendidikan dan kebudayaan nomor 22 tahun 2016 tentang standar proses pendidikan dasar dan menengah. Jakarta: Kemdikbud.

Liu, S.C., \& Lin, H.S. (2013). Primary teacher's beliefs about scientific creativity in the classroom context. International Journal of Science Education, 36(10), 1551-1567.

Moreno, R. (2010). Educational psichology. New Mecico. John Wiley \& Sons, Inc.

Mukhopadhyay, R. (2013). Measurement of creativity in physics: A brief review on related tools. Journal of Humanities and Social Science, 6(5), 45-50.

OECD. (2014). PISA 2012 results: Creative problem solving: Student's skills in tackling real-life problems (Volume V), PISA. Publishing: OECD.

Partnership for 21st Century Skills. (2009). Retrieved from http://www.p21.org/

Peraturan Presiden Nomor 8 Tahun 2012 tentang Kerangka Kualifikasi Nasional Indonesia.

Rotteram, K. (2014) Teaching, learning and creativity model for science. SSR, 95, 79-84.

Siswanto, J. (2018). Keefektifan pembelajaran fisika dengan pendekatan STEM untuk meningkatkan kreativitas mahasiswa. Jurnal Penelitian Pembelajaran Fisika, 9(2), 133137.

Slavin, R.E. (2011). Educational psikology, theori and practice. Boston: Pearson Education.

Stenberg, R.J. (2009). Academic intelligence is not enough WICS: An expanded model for effective practice in school and later in life. A Paper Commissioned for The Conference on Liberal Education and Effective Practice, Mosakowski Institute for Public Enterprise, March 12-13, 2009.

Suyidno, Dewantara, D., Nur, M., \& Yuanita, L. (2017). Maximize student's scientific process skill within creatively product design: creative responsibility based learning. Proceeding The 5th South East Asia Development Research (SEA-DR) International Conference. Banjarmasin, Indonesia, 3 Mei 2017

Suyidno, Nur, M., Yuanita, L., \& Salam, A.M. (2020). Creative responsibility based learning: Kreatif pendidiknya, dahsyat peserta didiknya. Banjarmasin: ULM Press.

Suyidno, Nur, M., Yuanita, L., Prahani, B. K., and Jatmiko, B. (2018). Effectiveness of creative responsibility based teaching (CRBT) model on basic physics learning to increase student's scientific creativity and responsibility. Journal of Baltic Science Education, 17(1), 136-151.

Suyidno, S., Susilowati, E., Arifuddin, M., Misbah, M., Sunarti, T., \& Dwikoranto, D. (2019). Increasing students' responsibility and scientific creativity through creative responsibility based learning. Jurnal Penelitian Fisika dan Aplikasinya, 9(2), 178-188.

Torrance, E. P. (2013). Scientific views of creativity and factors affecting its growth. The MIT Press and American Academy of Arts \& Sciences are collaborating with JSTOR to digitize, preserve and extend access to Daedalus. 
Turiman, P., Omar, J., Daud, A. M., \& Osman, K. (2012). Fostering the 21st century skills through scientific literacy and science process skills. Procedia-Social and Behavioral Sciences, 59, 110-116.

Yesil, R. (2013). The evaluation of responsibility education strategies of primary school teachers. Procedia-Social and Behavioral Sciences, 106, 2775- 2787.

Zakar, Z., \& Baykara, H. (2014). Inquiry-based laboratory practices in a science teacher training program. Eurasia Journal of Mathematics, Science and Technology Education, 10(2), 173-183.

\section{Corresponding Author:}

Ratna Pangastuti

Department of Early Childhood Islamic Education, UIN Sunan Ampel Surabaya

Jl. Ahmad Yani No.117, Jemur Wonosari, Kec. Wonocolo, Kota SBY, Jawa Timur 60237, Indonesia

Email: ratnapangastuti@uinsby.ac.id 